$11-25-2008$

\title{
Androgen-independent prostate cancer cells acquire the complete steroidogenic potential of synthesizing testosterone from cholesterol.
}

\author{
Paulette R. Dillard \\ Clark Atlanta University \\ Ming-Fong Lin \\ University of Nebraska Medical Center, mlin@unmc.edu \\ Shafiq A. Khan \\ Clark Atlanta University
}

Tell us how you used this information in this short survey.

Follow this and additional works at: https://digitalcommons.unmc.edu/com_bio_articles

Part of the Medical Biochemistry Commons, and the Medical Molecular Biology Commons

\section{Recommended Citation}

Dillard, Paulette R.; Lin, Ming-Fong; and Khan, Shafiq A., "Androgen-independent prostate cancer cells acquire the complete steroidogenic potential of synthesizing testosterone from cholesterol." (2008). Journal Articles: Biochemistry \& Molecular Biology. 35.

https://digitalcommons.unmc.edu/com_bio_articles/35

This Article is brought to you for free and open access by the Biochemistry \& Molecular Biology at DigitalCommons@UNMC. It has been accepted for inclusion in Journal Articles: Biochemistry \& Molecular Biology by an authorized administrator of DigitalCommons@UNMC. For more information, please contact digitalcommons@unmc.edu. 


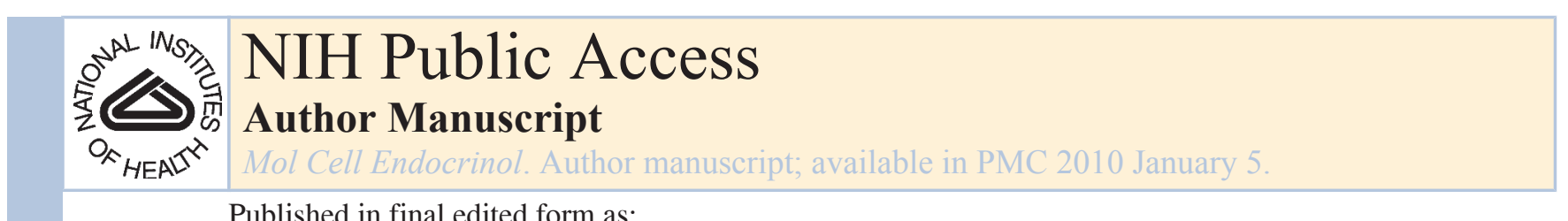

Published in final edited form as:

Mol Cell Endocrinol. 2008 November 25; 295(1-2): 115-120. doi:10.1016/j.mce.2008.08.013.

\title{
Androgen-independent prostate cancer cells acquire the complete steroidogenic potential of synthesizing testosterone from cholesterol
}

\author{
Paulette R. Dillard ${ }^{1}$, Ming-Fong Lin ${ }^{2}$, and Shafiq A. Khan ${ }^{1}$ \\ ${ }^{1}$ Department of Biological Sciences and Center for Cancer Research and Therapeutic \\ Development, Clark Atlanta University, Atlanta, GA 30314 \\ ${ }^{2}$ Department of Biochemistry and Molecular Biology and Eppley Institute for Cancer Research, \\ University of Nebraska Medical Center, Omaha, NE 68198
}

\begin{abstract}
The proliferation and differentiation of normal prostate epithelial cells depends upon the action of androgens produced by the testis. Prostate cancers retain the ability to respond to androgens in the initial stages of cancer development, but progressively become independent of exogenous androgens in advanced stages of the disease while maintaining the expression of functional androgen receptor (AR). In the present study, we have determined the potential of prostate cancer cells to synthesize androgens from cholesterol which may be involved in intracrine regulation of AR in advanced stages of the disease.. Established androgen- independent prostate cancer cell lines, PC 3 and DU145 cells, expressed mRNA and proteins for scavenger receptor type B1 (SRB1), steroidogenic acute regulatory (StAR) protein, cytochrome $\mathrm{P} 450$ cholesterol side chain cleavage (P450scc), 3 $\beta$-hydroxysteroid dehydrogenase ( $3 \beta$-HSD) and other enzymes involved in androgen biosynthesis. Expression of all these proteins and enzymes was significantly higher in the androgen-independent derivative of LNCaP prostate cancer cells (C81) than in the androgen-dependent cell line (C33). In serum-free cultures, the androgen-independent C 81 cells secreted $\sim 5$ fold higher testosterone than $\mathrm{C} 33$ cells as determined in the conditioned media by immunoassays. These cells could also directly convert radioactive cholesterol into testosterone which was identified by thin layer chromatography. These results for the first time show that prostate cancer cells in advanced stages of the disease could synthesize androgens from cholesterol and hence are not dependent upon testicular and/or adrenal androgens.
\end{abstract}

\section{Keywords}

prostate cancer; androgen-independence; androgen receptor; androgen biosynthesis; steroidogenesis; intracrine regulation

(C) 2008 Elsevier Ireland Ltd. All rights reserved.

Correspondence: Shafiq A. Khan, Ph.D., Center for Cancer Research and Therapeutic Development, Clark Atlanta University, 223 James P. Brawley Dr, SW, Atlanta, GA 30314, Tel: 404-880-6795, skhan@cau.edu.

Publisher's Disclaimer: This is a PDF file of an unedited manuscript that has been accepted for publication. As a service to our customers we are providing this early version of the manuscript. The manuscript will undergo copyediting, typesetting, and review of the resulting proof before it is published in its final citable form. Please note that during the production process errors may be discovered which could affect the content, and all legal disclaimers that apply to the journal pertain. 


\section{Introduction}

Prostate cancer is the most frequently diagnosed malignancy in men and the second leading cause of male cancer related deaths in the United States (Jemal, et. al., 2005). The majority of prostate cancers are dependent upon androgens at initial diagnosis, and endocrine therapy is directed toward removal of androgen source (castration) or inhibition of androgen synthesis in the testicular Leydig cells (Griffiths, et. al., 1997). However, there is a progressive loss of androgen dependency (castration-resistance) during advanced stages of prostate cancer and the tumor cells do not respond to hormonal treatments (Feldman and Feldman, 2001) indicating that these cells acquire the potential to survive and proliferate in the absence of exogenous testosterone (Chen, et. al., 2004).

Studies using archival patient samples have shown increased expression of androgen receptor (AR) in advanced stages of prostate cancer and/or that AR becomes supersensitive to androgens and antiandrogens (Chen, et. al., 2004,Gelmann, 2002,Mohler, et. al., 2004); a two to five fold increase in AR mRNA is the only gene expression change consistently associated with hormone refractory disease (Chen, et. al., 2004). Immunohistochemical localization studies show that AR is present in primary site and metastatic prostate cancers regardless of stage and grade, as well as in hormone refractory cancers (Mostaghel, et. al., 2007). These findings are supported by in vitro data showing that inhibition of AR expression in hormone refractory prostate cancer cells results in inhibition of growth and survival, indicating an essential role of AR in advanced stages of prostate cancer (Chen, et. al., 2004). These in vivo and in vitro studies suggest that some unknown factor(s) produced in prostate cancer cells is able to activate and maintain the function of AR (Gelmann, 2002). It has been recently shown that the levels of testosterone, DHT and androgen precursors in the prostate tissue of patients with recurrent prostate cancers following medical or surgical castration, are present at levels sufficient for AR activation (Mohler, et. al., 2004, Titus, et. al., 2005).

The possibility that the prostate cancer cells may acquire steroidogenic potential and may produce androgens which bind to AR and stimulate gene expression has also been explored (Ellem, et. al., 2004,Holzbeierlein, et. al., 2004). Several studies have indicated that other steroidal ligands such as estradiol may be able to activate AR (Kaplan, 1969). The AR in these cells may be mutated causing hypersensitivity of the receptor and the promiscuous usage of other steroid ligands such as cortisol, estrogen, and progesterone (Gelmann, 2002). Expression of aromatase which converts androgens to estrogens, is also altered in prostate cancer cells (Ellem and Risbridger, 2006). Therefore, it has been postulated that prostate cancer cells are capable of converting steroid precursors into androgens and estrogens which serve as ligands for their respective receptors (El-Alfy, et. al., 1999,Nakamura, et. al., 2005). The central hypothesis in the previous studies have focused on either the role of low (castration) levels of serum androgens or androgens synthesized from adrenal precursors as potential regulators of AR in hormone refractory advanced prostate cancers. However, the possibility that prostate cancer cells acquire complete steroidogenic potential to synthesize androgens from cholesterol has not been explored, although upregulation of genes involved in cholesterol biosynthesis from acetate in androgen independent prostate cancers has been reported (Holzbeierlein, et. al., 2004,Stanbrough, et. al., 2006); In this study we demonstrate for the first time the expression of cellular proteins involved in key steps in steroidogenesis in the prostate cancer model cell lines and show that prostate cancer cells are capable of producing testosterone directly from cholesterol. 


\section{Materials and Methods}

\section{Cell lines and cell culture}

Human prostate cancer cell lines DU145 and PC3 were purchased from American Type Cell Culture Collection (Rockville, MD). Clonetics ${ }^{\circledR}$ normal human prostate epithelial cells (PrEC) were purchased from Lonza (Allendale, NJ). For these experiments, LNCaP prostate cancer cell progression model (Igawa, et. al., 2002) includes cells that have passage numbers less than 33 are designated as clone $33(\mathrm{C} 33)$ and the passage numbers over 80 as clone 81 (C81). These cell lines recapitulate the phenomenon of clinical tumor progression and C81 cells express PSA in the absence of exogenous androgens (Igawa, et. al., 2002). DU145 and PC3 cells were cultured in Eagle's minimum essential medium with Earle's salts and amino acid supplements (Millena, et. al., 2004). LNCaP -C33, and-C81 cells were routinely maintained in RPMI 1640 (Igawa, et. al., 2002) containing 10\% fetal bovine serum (HyClone, South Logan, Utah). PrEC cells were cultured in Prostate Epithelial Cell Basal Medium according to the supplier's instructions. RNA and total proteins from H295R adrenal carcinoma and JEG3 choriocarcinoma cells were provided by Dr. Marion Sewer (Georgia Institute of Technology, Atlanta) and were used as positive controls for steroidogenic proteins and enzymes.

\section{RNA isolation, cDNA synthesis and RT-PCR}

For RT-PCR analysis, cells were cultured in 6-well plates overnight in the presence of $10 \%$ FBS. After 24h, cells were washed with $1 \times$ PBS, and cultured in serum-free media for $48 \mathrm{~h}$. Total RNA was isolated from the cells using TRIzol (Invitrogen, Carlsbad, CA) and quantified by optical density reading at $260 \mathrm{~nm}$ as described earlier (Millena, et. al., 2004). PCR reactions were performed using MasterCycler gradient (Eppendorf AG, Hamburg, Germany) using the procedures described previously (Millena, et. al., 2004). For PCR, $2 \mu 1$ of cDNA were added to separate PCR reaction mixtures (total $10 \mu \mathrm{l}$ ) containing $0.1 \mathrm{mM}$ dNTPs, (Promega, Madison, WI), 0.5 U Taq DNA polymerase (PGC Scientifics, Frederick, MD), $1 \times$ standard PCR buffer with $1.5 \mathrm{mM} \mathrm{MgCl}_{2}$ and $25 \mathrm{pmol}$ of gene-specific primers. Cycling conditions for the MasterCycler were $94^{\circ} \mathrm{C}$ for $2 \mathrm{~min}$ (initial denaturation), $94^{\circ} \mathrm{C}$ for $1 \mathrm{~min}, 60^{\circ} \mathrm{C}$ or $62^{\circ} \mathrm{C}$ for 1 $\min , 72^{\circ} \mathrm{C}$ for $2 \mathrm{~min}$ for $30-35$ cycles, and $72^{\circ} \mathrm{C}$ for $5 \mathrm{~min}$ (final extension). L19 (a ribosomal protein) primer pair was used as an internal control. The oligonucleotide pair for L19 was synthesized according to previously published report (Millena, et. al., 2004). All other genespecific primers were designed using Beacon Designer 5.0 (Premier Biosoft International, Palo Alto, CA) software program. Sequences of all primers used in RT-PCR experiments are shown in Table 1. The PCR products were visualized on $1.5 \%$ agarose gels stained with ethidium bromide. Relative amounts of PCR products were estimated by digital densitometry (GEAmersham, Piscataway, NJ). Density values for each gene-specific PCR band was normalized with L19 bands. The PCR products were sequenced to confirm the identities of the specific mRNAs. Three independent experiments were performed and the data analyzed using student t-test and ANOVA. Representative RT-PCR results are shown in the figures.

\section{Western blot analyses}

The antibodies against StAR, P450scc and Cyp 17 were obtained from Dr. Buck Hales (University of Illinois, Chicago). Cells were cultured in $10 \mathrm{~cm}^{2}$ dishes to $70 \%$ confluency, washed twice with PBS and lysed in cell lysis buffer (Cell Signaling Technology, Beverly, $\mathrm{MA}$ ) and the protein concentrations were determined as described previously (Millena, et. al., 2004). Cell lysates were mixed with Laemmli's buffer (62.5 mM Tris, pH 6.8, 2\% SDS, 5\% $\beta$-mercaptoethanol and $10 \%$ glycerol) and individual samples (30 $\mu \mathrm{g}$ protein) were subjected to SDS-PAGE in 10\% gels and transferred to PVDF membranes (Millipore, Bedford, MA). Western blot analyses were performed by the procedures described previously (Millena, et. al., 2004). The membranes were incubated with appropriate dilutions of specific primary antibodies (over night at $4^{\circ} \mathrm{C}$ ) and with secondary antibodies (anti-rabbit or anti-mouse 
immunoglobulin coupled to horseradish peroxidase) at appropriate dilutions for $1 \mathrm{~h}$ at room temperature. Western blots for $\beta$-actin were carried out in parallel as loading controls. The relative intensities of specific protein bands were determined by densitometric analysis of images using ImageQuant software (GE-Amersham).

\section{Radioimmunassay of testosterone}

LNCaP- C33, -C81, DU145 and PC3 cells were plated in 6-well plates and cultured in serum free medium for 48 hours, after which conditioned media were collected and analyzed for total androgens using a radioimmunoassay (Millena, et. al., 2004). The antiserum employed in this immunoassay exhibits 77 and $26 \%$ cross-reactivity to $5 \alpha$-dihydrotestosterone and $5 \alpha-$ androstane, $3 \alpha, 17 \beta$ diol, respectively and hence is ideal for determination of total androgens (Ismail, et. al., 1972).

\section{Thin layer chromatography (TLC)}

LNCaP-C33, -C81, DU145, and PC 3 cells were plated in six well plates $\left(10^{6}\right.$ cells/well), treated with ${ }^{3} \mathrm{H}$-Cholesterol $(1 \mu \mathrm{Ci}, 34 \mu \mathrm{M})$ in $1 \mathrm{ml}$ of serum-free medium and incubated for 48 hours. The cells and media were extracted twice with chloroform/acetone (1:1, v/v) (Schmidt, et. al., 2005). The combined extracts were dried at $76^{\circ} \mathrm{C}$, subjected to TLC on silica gel G plates and developed with chloroform/diethylether (1:1, v/v) (Schmidt, et. al., 2005).Purified unlabeled cholesterol and testosterone standards were either added to the cell extracts or ran in parallel on the TLC plates. For identification of spots the silica gel plates were stained using phosphomolybdic acid then dried with a heat gun (Schmidt, et. al., 2005). Blue-black spots were visualized identifying the locations of the testosterone and cholesterol standards. Spots were excised, added to liquid scintillation fluid and radioactivity was determined using a scintillation counter (Schmidt, et. al., 2005).

\section{Results and Discussion}

The results described in this study show for the first time that androgen-independent human prostate cancer cells are able to acquire complete steroidogenic potential and are capable of synthesizing testosterone from cholesterol, indicating an intracrine regulation of AR in advanced stages of prostate cancer. Several studies have shown the expression of key steroidogenic enzymes in prostate cancer cells indicating that these cells are able to synthesize androgens from adrenal precursors (El-Alfy, et. al., 1999,Nakamura, et. al., 2005,Stanbrough, et. al., 2006). The presence of functional AR in advanced stages of the disease and the presence of testosterone and DHT, sufficient to activate the AR, in cancer tissues under androgen ablation therapy, also support this notion (Gelmann, 2002,Mohler, et. al., 2004,Titus, et. al., 2005). The purpose of our studies was to determine whether prostate cancer cells in advanced stages of the disease can synthesize testosterone from cholesterol hence making them completely independent of serum testosterone and/or adrenal steroid precursors.

Figure 1 shows the key components of steroidogenic machinery required for cholesterol uptake (SRB-1), cholesterol transport into inner mitochondrial membrane (StAR protein) and enzymes required to convert cholesterol into pregnenolone ( $\mathrm{P} 450 \mathrm{scc})$ and subsequently into testosterone (Stocco, 2001). As a first step we determined the expression of SRB-1, StAR, P450scc, $3 \beta \mathrm{HSD}, \mathrm{CYP} 17$ and 17ßHSD1 in normal prostate epithelial cells (PrEC) and two established androgen-independent prostate cancer cell lines (DU145 and PC3), along with human adrenal carcinoma (H295R) and choriocarcinoma (JEG3) cell lines (Figure 2). RT-PCR analyses revealed very low or undetectable expression of StAR, P450scc and CYP17 in PrEC cells. However, expression of all components of steroidogenesis was detected in both DU145 and PC 3 cells. The expression of StAR was detected at a low level in these cells compared to H295R cells. The placental cells (JEG3) are known not to express StAR protein and to use other 
members of this protein family to transport cholesterol into mitochondria (Watari, et. al., 1997). All cell lines including PrEC cells expressed comparable levels of 17 $\beta$-HSD1 which was confirmed by sequencing the PCR-product. Previous studies have identified different isoforms of $17 \beta$-HSD in several tissues have shown that while $17 \beta$-HSD1 and $17 \beta$-HSD5 are present in prostate cancer cells, 17 $\beta$ - HSD3 is primarily expressed in the testis (Labrie, et. al., 1997). Previous studies have shown the presence of $17 \beta-$ HSD1 in the prostate, and in LNCaP cells using RNAse protection assays (Labrie, et. al., 1997). However, another study failed to detect 17 $\beta$ - HSD1 in prostate cancer cell lines (LNCap, DU145, PC3) using northern blotting (Castagnetta, et. al., 1997). The reasons for this discrepancy could be due to the differential sensitivity of methods employed by the two studies.

To determine whether the expression of steroidogenic machinery correlates with independence from exogenous testosterone, we employed cell lines derived from LNCaP cells, which represent this phenomenon in vitro. $\mathrm{C} 33$ and $\mathrm{C} 81$ cells are both AR positive, however $\mathrm{C} 33$ cells are androgen dependent and C81 cells do not require exogenous androgens for survival and proliferation (Igawa, et. al., 2002). These cell lines recapitulate the phenomenon of clinical tumor progression and have been validated and used as models of androgen-independent cells in subsequent studies from different laboratories (Cai, et. al., 2007, Cao, et. al., 2006,Denmeade, et. al., 2003,Unni, et. al., 2004). PSA secretion by C81 cells in the absence of androgens is much higher than that secreted by $\mathrm{C} 33$ cells which is a biomarker for androgen-independence and is seen in other in vitro models of androgen independent prostate cancers (Chen, et. al., 2007,Hara, et. al., 2003). Data presented in Figure 3A confirmed the presence of AR mRNA and protein in C33 and C81 cells (Igawa, et. al., 2002) and showed no expression of AR in PC3 and DU145 cells. The presence of functional AR makes C33 and C81 cells a better model for these studies. We determined the expression of all steroidogenic enzymes and proteins in C33 and C81cells by RT-PCR as described above. The results of these determinations are presented in Figure 3B. All key components of steroidogenic machinery are expressed in androgen-independent C81 cells. Both C33 and C81 cells expressed SRB1, P450scc, 3 3 HSD and 17ßHSD1 at comparable levels; however StAR expression was low in C33 cells compared to $\mathrm{C} 81$ cells and no expression of CYP17 was detected in C33 cells. The steady state mRNA levels for StAR and P450scc in C81 cells were 4.7-fold and 1.3-fold higher than those in C33 cells, respectively. Similar differences in the expression of StAR mRNA were observed using real time PCR analysis (data not shown). These results were confirmed using Western blot analysis as shown in Figure 3C. StAR protein was not detected in PrEC cells and is present at low levels in C33 cells. C81 cells contained higher amount of StAR protein when compared with C33 cells. The protein levels of StAR and P450scc in C81 cells were 2.6-fold and 1.7fold higher than those in $\mathrm{C} 33$ cells. We also detected presence of StAR protein in PC3 and DU145 cells. Our results also showed that CYP17 is not expressed either at mRNA or at protein level in PrEC and C33 cells; however, significant expression of CYP17 mRNA and protein were present in C81 cells. Since StAR is critical for cholesterol transport into mitochondria and CYP17 is required for androgen synthesis from progesterone, C33 cells may have very low or limited capacity to synthesize androgen from cholesterol (Stocco, 2001).

These data suggest that androgen independence in prostate cancer cell lines correlates with the acquisition of proteins required for androgen biosynthesis from cholesterol. To determine whether these cells synthesize androgens in vitro, the cells were cultured for $48 \mathrm{hr}$ in serumfree media and androgen levels were determined in conditioned media using RIA. As shown in Figure 4A, detectable levels of androgens were present in the conditioned media from both C33 and C81 cells cultured in the absence of serum. Nevertheless, C81 cells secreted approximately five-fold higher androgens than C33 cells. Levels of androgens in the conditioned media from PC3 and DU145 cells and also in unrelated control cells or in the culture medium without the cells were undetectable (HeLa, COS; data not shown). These data show that androgen independence is indeed associated with androgen secretion by $\mathrm{C} 81$ cells 
in the absence of exogenous steroid precursors. The reason for undetectable levels of testosterone in conditioned media from PC 3 and DU145 cells could be due to a) low production of testosterone by these cells as a consequence of low expression of StAR, or b) due to its conversion to estradiol by aromatase. The second possibility is supported by high levels of aromatase in these cell lines (Dillard et al, unpublished data;(Ellem and Risbridger, 2006); androgens may be irrelevant in these cell lines since they do not express AR.

To confirm that the $\mathrm{C} 33$ and $\mathrm{C} 81$ cells are capable of using cholesterol uptake and its conversion into androgens, we determined the conversion of labeled exogenous cholesterol to testosterone in these cells. The cells were cultured in the presence of $1 \alpha, 2 \alpha[\mathrm{N}]-{ }^{3} \mathrm{H}$-cholesterol for $48 \mathrm{hr}$ in serum-free medium. The conditioned media and cell extracts were then analyzed for the presence of labeled testosterone by TLC. Figure 4B shows the separation of testosterone and cholesterol by TLC (upper panel). The spots representing cholesterol and testosterone were scraped and counted in the scintillation counter. The results showed conversion of radiolabeled cholesterol into tesotosterone by both cell lines. The radioactivity observed in C33 cells was $3613 \pm 1004 \mathrm{cpm}$ and $191 \pm 45 \mathrm{cpm}(\mathrm{Mean} \pm \mathrm{SEM} ; \mathrm{n}=3)$ for cholesterol and testosterone spots, respectively. The corresponding radioactive in C81 cells was $3268 \pm 1309$ and $225 \pm 45$, for cholesterol and testosterone, respectively. The differences in the levels of radioactive testosterone were not statistically significant and were different than those observed for RIA. The reason for this discrepancy were probably due to the fact that RIA determines the levels of all androgens while only testosterone spots were analyzed in the TLC. Any conversion of testosterone into DHT or other metabolites may account for these differences. In addition, while only conditioned media were analyzed in the RIA, both cell extracts and media were combined for TLC analysis. Nevertheless, it should also be noted that DHT is more active form of androgens than $\mathrm{T}$ in prostate cells. Additional studies involving separation of all androgenic steroids and analysis will be required to clarify this point. However, the fact that we did find radioactive testosterone in these cells and since radioactive testosterone could only be synthesized from radioactive cholesterol, this experiment conclusively demonstrated that these cells are capable of making androgens directly from exogenous cholesterol. The specificity of this conversion was also supported by the fact that we did not detect any radioactive testosterone in DU145 and PC3 cells (data not shown) confirming our RIA results.

Mohler and collaborators (Mohler, et. al., 2004,Titus, et. al., 2005) reported the presence of significant amounts of testosterone and DHT in the recurrent prostate cancer tissues and suggested that prostate cancer cells may synthesize androgens from adrenal precursors or cholesterol (El-Alfy, et. al., 1999,Nakamura, et. al., 2005,Stanbrough, et. al., 2006). Our studies support the notion that this testosterone can be synthesized directly from cholesterol. This possibility is also supported by the fact that genes regulating cholesterol biosynthesis are upregulated in androgen ablation resistant prostate cancer cells (Holzbeierlein, et. al., 2004) suggesting that prostate cancer cells may also be able to increase biosynthesis of intracellular cholesterol.

In conclusion, our results clearly show for the first time that advanced androgen independent prostate cancer cells acquire complete steroidogenic ability to synthesize androgens and underline the fact that castration and inhibition of testosterone production in the testes may not achieve androgen deficiency in prostate cancer cells in advanced stages of the disease. Our results also explain the essential role of AR in survival and proliferation of androgenindependent prostate cancers under androgen-ablation therapy and suggest that inhibitors of steroid biosynthesis in prostate cancer cells may be required to completely abolish the androgens in these tumors for its therapy. 


\section{Acknowledgments}

We are thankful to Mrs. Ana Cecilia Millena for expert technical assistance. These studies were supported by NIH grants, G12RR003062 (S.K.; P.D.) and CA88184 (M.F.L.) and DOD grant W81XWH-08-1-0077 (S.K.).

\section{References}

Cai C, Chen SY, Zheng Z, Omwancha J, Lin MF, Balk SP, Shemshedini L. Androgen regulation of soluble guanylyl cyclasealpha1 mediates prostate cancer cell proliferation. Oncogene 2007;26:16061615. [PubMed: 16964290]

Cao X, Qin J, Xie Y, Khan O, Dowd F, Scofield M, Lin MF, Tu Y. Regulator of G-protein signaling 2 (RGS2) inhibits androgen-independent activation of androgen receptor in prostate cancer cells. Oncogene 2006;25:3719-3734. [PubMed: 16449965]

Castagnetta LA, Carruba G, Traina A, Granata OM, Markus M, Pavone-Macaluso M, Blomquist CH, Adamski J. Expression of different 17beta-hydroxysteroid dehydrogenase types and their activities in human prostate cancer cells. Endocrinology 1997;138:4876-4882. [PubMed: 9348218]

Chen CD, Welsbie DS, Tran C, Baek SH, Chen R, Vessella R, Rosenfeld MG, Sawyers CL. Molecular determinants of resistance to antiandrogen therapy. Nat Med 2004;10:33-39. [PubMed: 14702632]

Chen SJ, Karan D, Johansson SL, Lin FF, Zeckser J, Singh AP, Batra SK, Lin MF. Prostate-derived factor as a paracrine and autocrine factor for the proliferation of androgen receptor-positive human prostate cancer cells. Prostate 2007;67:557-571. [PubMed: 17221842]

Denmeade SR, Sokoll LJ, Dalrymple S, Rosen DM, Gady AM, Bruzek D, Ricklis RM, Isaacs JT. Dissociation between androgen responsiveness for malignant growth vs. expression of prostate specific differentiation markers PSA, hK2, and PSMA in human prostate cancer models. Prostate 2003;54:249-257. [PubMed: 12539223]

El-Alfy M, Luu-The V, Huang XF, Berger L, Labrie F, Pelletier G. Localization of type 517 betahydroxysteroid dehydrogenase, 3beta-hydroxysteroid dehydrogenase, and androgen receptor in the human prostate by in situ hybridization and immunocytochemistry. Endocrinology 1999;140:14811491. [PubMed: 10067877]

Ellem SJ, Risbridger GP. Aromatase and prostate cancer. Minerva Endocrinol 2006;31:1-12. [PubMed: 16498360]

Ellem SJ, Schmitt JF, Pedersen JS, Frydenberg M, Risbridger GP. Local aromatase expression in human prostate is altered in malignancy. J Clin Endocrinol Metab 2004;89:2434-2441. [PubMed: 15126575]

Feldman BJ, Feldman D. The development of androgen-independent prostate cancer. Nat Rev Cancer 2001;1:34-45. [PubMed: 11900250]

Gelmann EP. Molecular biology of the androgen receptor. J Clin Oncol 2002;20:3001-3015. [PubMed: 12089231]

Griffiths K, Morton MS, Nicholson RI. Androgens, androgen receptors, antiandrogens and the treatment of prostate cancer. Eur Urol 1997;32:24-40. [PubMed: 9267783]

Hara T, Nakamura K, Araki H, Kusaka M, Yamaoka M. Enhanced androgen receptor signaling correlates with the androgen-refractory growth in a newly established MDA PCa 2b-hr human prostate cancer cell subline. Cancer Res 2003;63:5622-5628. [PubMed: 14500404]

Holzbeierlein J, Lal P, LaTulippe E, Smith A, Satagopan J, Zhang L, Ryan C, Smith S, Scher H, Scardino $\mathrm{P}$, Reuter V, Gerald WL. Gene expression analysis of human prostate carcinoma during hormonal therapy identifies androgen-responsive genes and mechanisms of therapy resistance. Am J Pathol 2004;164:217-227. [PubMed: 14695335]

Igawa T, Lin FF, Lee MS, Karan D, Batra SK, Lin MF. Establishment and characterization of androgenindependent human prostate cancer LNCaP cell model. Prostate 2002;50:222-235. [PubMed: 11870800]

Ismail AA, Niswender GD, Midgley AR Jr. Radioimmunoassay of testosterone without chromatography. J Clin Endocrinol Metab 1972;34:177-184. [PubMed: 5061771]

Jemal A, Ward E, Hao Y, Thun M. Trends in the leading causes of death in the United States, 19702002. Jama 2005;294:1255-1259. [PubMed: 16160134]

Kaplan L. Estrogens and cancer of the prostate. Surg Gynecol Obstet 1969;128:117. [PubMed: 5774991] 
Labrie F, Luu-The V, Lin SX, Labrie C, Simard J, Breton R, Belanger A. The key role of 17 betahydroxysteroid dehydrogenases in sex steroid biology. Steroids 1997;62:148-158. [PubMed: 9029730]

Millena AC, Reddy SC, Bowling GH, Khan SA. Autocrine regulation of steroidogenic function of Leydig cells by transforming growth factor-alpha. Mol Cell Endocrinol 2004;224:29-39. [PubMed: 15353178]

Mohler JL, Gregory CW, Ford OH 3rd, Kim D, Weaver CM, Petrusz P, Wilson EM, French FS. The androgen axis in recurrent prostate cancer. Clin Cancer Res 2004;10:440-448. [PubMed: 14760063]

Mostaghel EA, Page ST, Lin DW, Fazli L, Coleman IM, True LD, Knudsen B, Hess DL, Nelson CC, Matsumoto AM, Bremner WJ, Gleave ME, Nelson PS. Intraprostatic androgens and androgenregulated gene expression persist after testosterone suppression: therapeutic implications for castration-resistant prostate cancer. Cancer Res 2007;67:5033-5041. [PubMed: 17510436]

Nakamura Y, Suzuki T, Nakabayashi M, Endoh M, Sakamoto K, Mikami Y, Moriya T, Ito A, Takahashi $\mathrm{S}$, Yamada S, Arai Y, Sasano H. In situ androgen producing enzymes in human prostate cancer. Endocr Relat Cancer 2005;12:101-107. [PubMed: 15788642]

Schmidt M, Weidler C, Naumann H, Anders S, Scholmerich J, Straub RH. Androgen conversion in osteoarthritis and rheumatoid arthritis synoviocytes--androstenedione and testosterone inhibit estrogen formation and favor production of more potent 5alpha-reduced androgens. Arthritis Res Ther 2005;7:R938-R948. [PubMed: 16207335]

Stanbrough M, Bubley GJ, Ross K, Golub TR, Rubin MA, Penning TM, Febbo PG, Balk SP. Increased expression of genes converting adrenal androgens to testosterone in androgen-independent prostate cancer. Cancer Res 2006;66:2815-2825. [PubMed: 16510604]

Stocco DM. StAR protein and the regulation of steroid hormone biosynthesis. Annu Rev Physiol 2001;63:193-213. [PubMed: 11181954]

Titus MA, Schell MJ, Lih FB, Tomer KB, Mohler JL. Testosterone and dihydrotestosterone tissue levels in recurrent prostate cancer. Clin Cancer Res 2005;11:4653-4657. [PubMed: 16000557]

Unni E, Sun S, Nan B, McPhaul MJ, Cheskis B, Mancini MA, Marcelli M. Changes in androgen receptor nongenotropic signaling correlate with transition of $\mathrm{LNCaP}$ cells to androgen independence. Cancer Res 2004;64:7156-7168. [PubMed: 15466214]

Watari H, Arakane F, Moog-Lutz C, Kallen CB, Tomasetto C, Gerton GL, Rio MC, Baker ME, Strauss JF 3rd. MLN64 contains a domain with homology to the steroidogenic acute regulatory protein (StAR) that stimulates steroidogenesis. Proc Natl Acad Sci U S A 1997;94:8462-8467. [PubMed: 9237999] 


\section{HDL/LDL CHOLESTEROL}
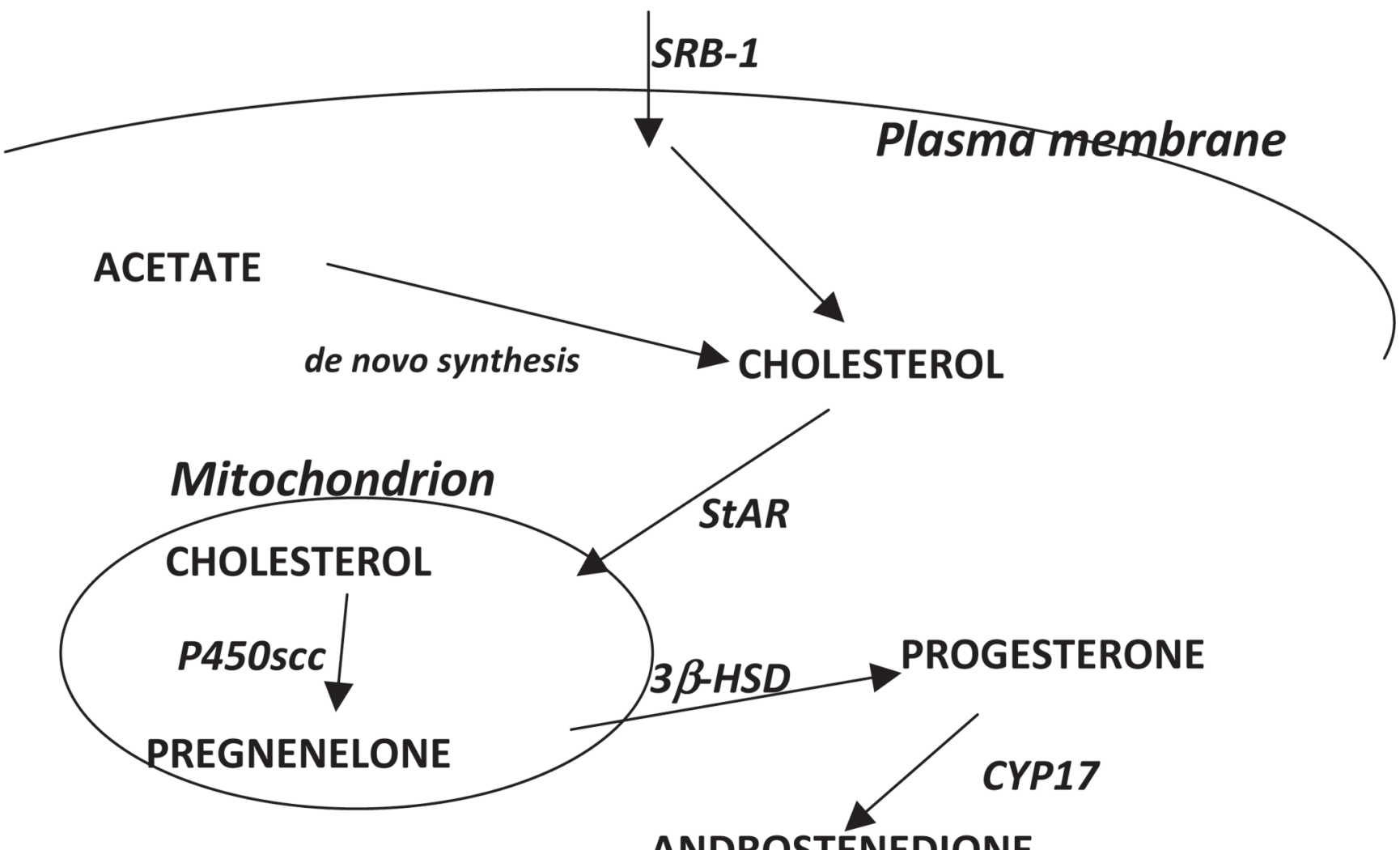

ANDROSTENEDIONE

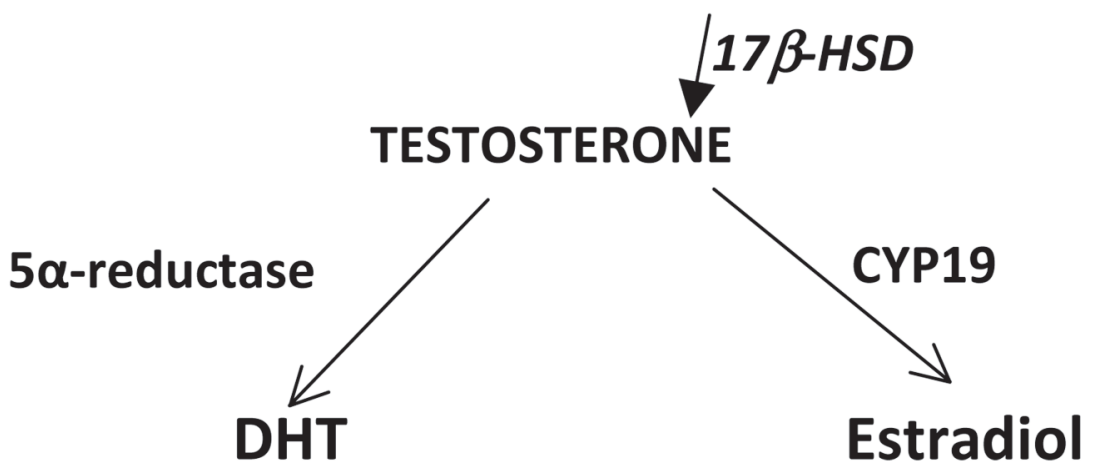

Fig 1.

Diagram illustrating pathways involved in biosynthesis and metabolism of testosterone. 


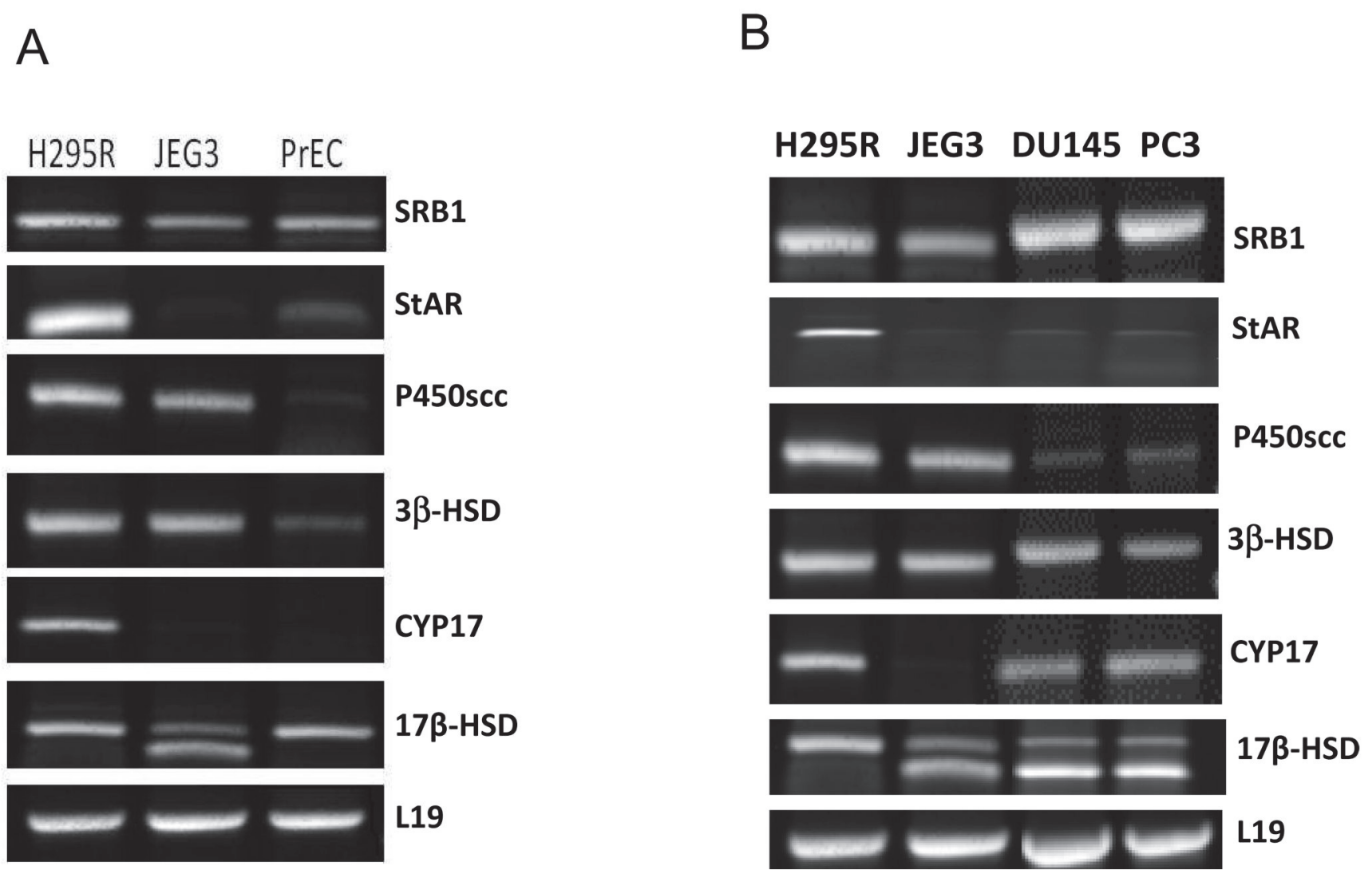

Fig 2.

RT-PCR analysis of mRNAs fro steroidogenic enzymes and other proteins required for androgen biosynthesis in normal prostate epithelial cells (PrEC; 2A) and androgen independent prostate cancer cell lines (PC3 and DU 145; 2B). Established steroidogenic cell lines (H295R and JEG3) served as positive controls. 
A
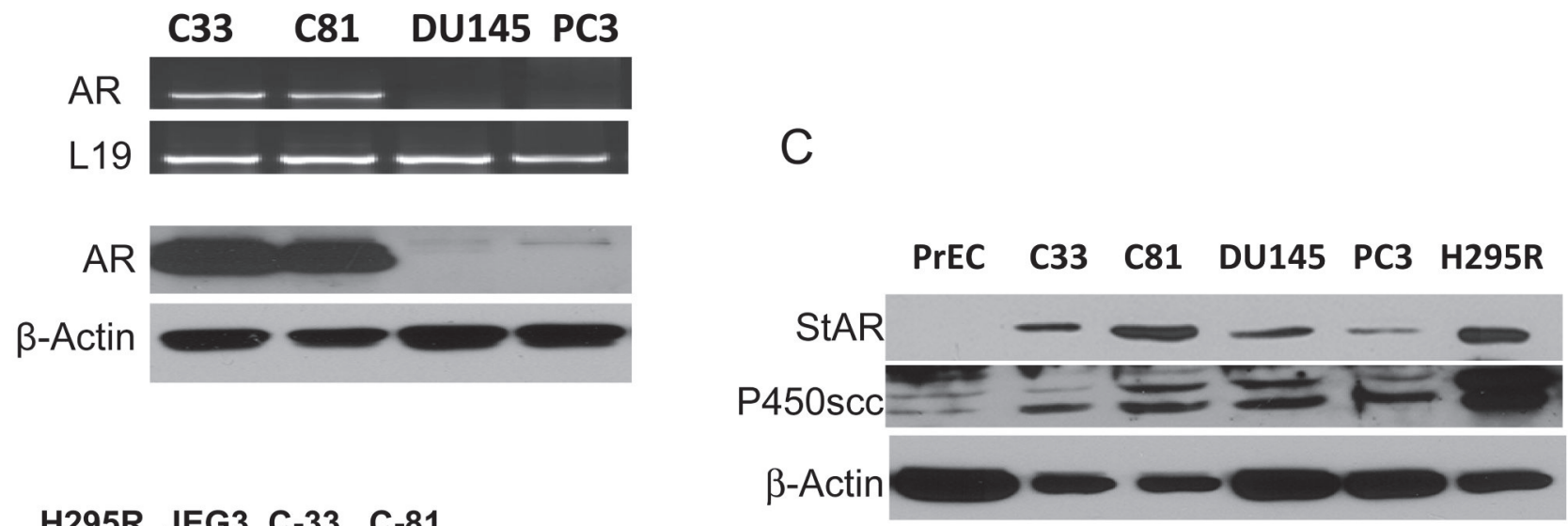

H295R JEG3 C-33 C-81

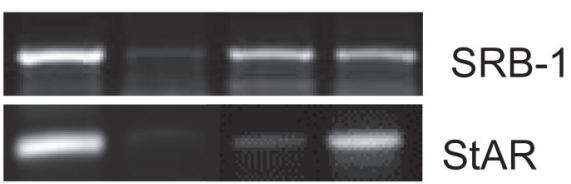

P450scc
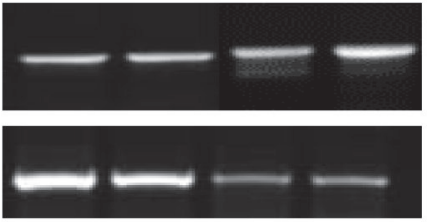

$3 \beta-H S D$

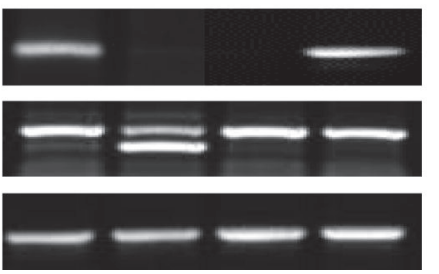

CYP 17

$17 \beta-H S D$

Fig 3.

Expression of AR and steroidogenic machinery in prostate cancer cells

A. RT-PCR (upper panel) and Western blot (lower panel) analysis of AR mRNA and protein in C33 (androgen dependent), C81 (androgen independent), and AR negative DU145, and PC3 prostate cancer cell lines. Ribosomal L19 and $\beta$-actin were used as controls in RT-PCR and Western blots, respectively.

B. RT-PCR analysis of steroidogenic enzymes and other proteins required for androgen biosynthesis in C33 and C81 prostate carcinoma cells.

C. Western blotting for StAR, P450scc (upper panel), and CYP17 (lower panel) protein in C33, C81, DU145 and PC3, PrEC, and H295R cells. 
A

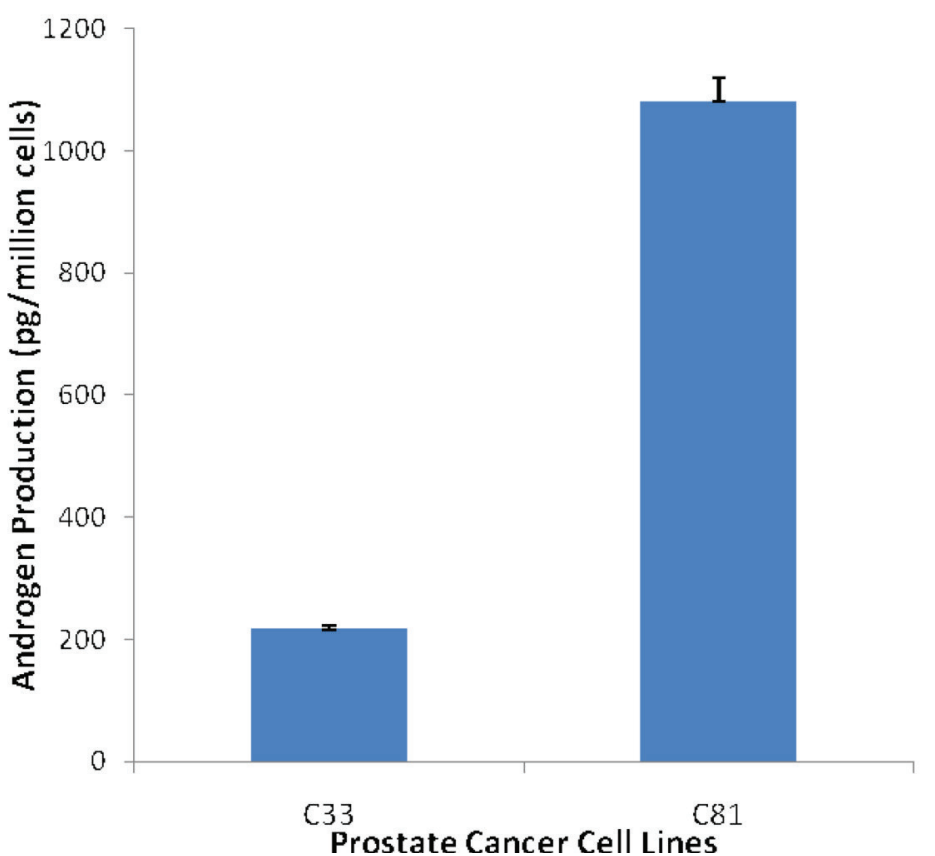

B

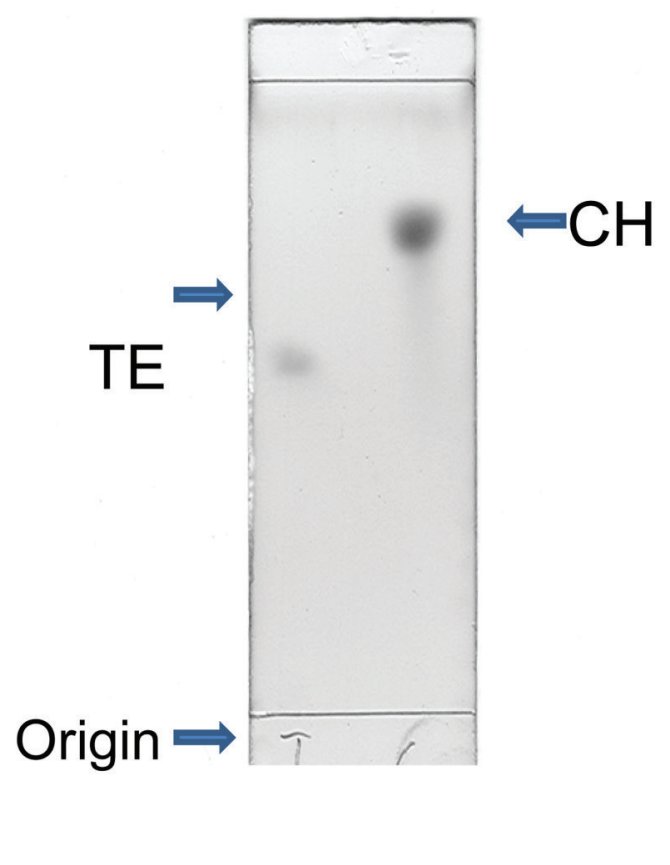

Fig 4.

Androgen production in androgen dependent (C33) and androgen independent (C81) prostate carcinoma cells

A. The cells were cultured in serum-free medium for $48 \mathrm{hr}$ and the conditioned media were collected and analyzed for androgen content by radioimmunoassay. Each bar represents Mean \pm SD from triplicate determinations.

B. Thin layer chromatography (TLC) separation of testosterone and cholesterol in C33 and $\mathrm{C} 81$ prostate cancer cells. The cells were cultured in serum-free medium containing ${ }^{3} \mathrm{H}-$ cholesterol $(1 \mu \mathrm{ci} / \mathrm{ml})$ for $48 \mathrm{hr}$ and the cells and conditioned media were collected. The cells and media were combined and extracted and the extracts were subjected to TLC. Purified unlabeled cholesterol and testosterone standards were added to the cell extracts for identification of spots using phosphomolybdic acid. Blue-black spots identifying the locations of the testosterone and cholesterol standards (4B) were excised, added to liquid scintillation fluid and radioactivity was determined using a scintillation counter. An equivalent spot from an unrelated area of the TLC plate was used as background. 
Table 1

Primer Sequences for RT-PCR

\begin{tabular}{lllc}
\hline Gene & Sense Primer & Antisense Primer & Product Size (bp) \\
\hline SRB-1 & AGGCATTGGACAAACTGGGAAG & TGTCATCAGGGATTCAGAATAGGC & 296 \\
StAR & ACCCGTTGGCTGGAAGTC & GATTCTCCTGATGAGCGTGTG & 238 \\
CYP11 & CGTCATTTTTGGGGAGCGCC & TGCAGGGTCATGGACGTCGT & 372 \\
$3 \beta-$ HSD & GGGCCCAACTCCTACAAGGA & ACTTGGGGCCTTCTTGGGGT & 356 \\
CYP17 & AGCTCGTGGCTCTCTTGCTG & CGCGATGTCTAGAGTTGCCA & 307 \\
17ß-HSD & GTGCTCATCACCGGCTGTTC & GGCCACGGATTTTGAGTCCC & 207 \\
L19 & GAAATCGCCAATGCCAACTC & TCTTAGACCTGCGAGCCTCA & 405 \\
GAPDH & GAAGGTGAAGGTTCGGAGTC & GAAGATGGTGATGGGATTTC & 200 \\
\hline
\end{tabular}

